\title{
Особливості прояву
}

\section{ПОСТТРАВМАТИЧНОГО СТРЕСОВОГО PОЗАААУ в соціАльному просторі}

Ostrovska K. O. Features of manifestation of posttraumatic stress disorder in social space / K. O. Ostrovska // Problems of Modern Psychology : Collection of research papers of Kamianets-Podilskyi National Ivan Ohiienko University, G. S. Kostiuk Institute of Psychology of the National Academy of Educational Sciences of Ukraine / scientific editing by S. D. Maksymenko, L. A. Onufriieva. - Issue 40. - KamianetsPodilskyi : Aksioma, 2018. - P. 295-306.

K. O. Ostrovska. Features of manifestation of posttraumatic stress disorder in social space. The article states that posttraumatic stress disorder, as a consequence of the manifestation of stress-related effects, is characterized by the symptoms such as: traumatic event experience, symptoms of avoidance and physiological hyperactivation, unmotivated vigilance and constant readiness for danger (danger).

A clinical picture of PTSD is presented including: social avoidance, distancing and alienation from others, sleep disorders, alcohol or drug abuse, high levels of anxiety or psychological instability, behavioral changes, antisocial behavior or wrongful acts, depressive, suicidal thoughts. Depressive disorders for DSM- 5 are presented.

Social stress disorder is manifested to clinical (psychological reactions) and clinical (neurosis, patho-haematological development of personality, alcoholism) disorders. The main clinical manifestations of social stress disorder are: autonomic dysfunction, sleep disturbance, asthenic disorder, hysterical disorders, panic disorder, other neurotic and psychopathic disorders.

Attention is drawn to the fact that early prevention and effective diagnosis with the use of types of psychological care will contribute to the complete processing and neutralization of socio-psychological maladaptation and to eliminate the long-term consequences of stressful effects.

Key words: posttraumatic stress disorder, psychological trauma, social adaptation, hyperactivation, hypertension.

К. О. Островська. Особливості прояву посттравматичного стресового розладу в соціальному просторі. У статті визначено, що особливості прояву посттравматичного стресового розладу (далі - ПТСР), як наслідок прояву стресогенного впливу, характеризуються такими симптомами: причепливого повторного переживання травматичної по- 
дії, уникнення і фізіологічної гіперактивації, невмотивованої пильності та постійної готовності до загрози (небезпеки). Представлено клінічну картину ПТСР, яка включає в себе: соціальне уникнення, дистанціювання і відчуження від інших, порушення сну, зловживання алкоголем або наркотиками, високий рівень тривожної напруженості чи психологічної нестійкості, зміни поведінки, антисоціальну поведінку або протиправні дії, депресивні, суїцидальні думки. Представлено депресивні розлади за DSM-5.

Звернено увагу на те, що завчасна профілактика й ефективна діагностика, із застосуванням видів психологічної допомоги, сприятимуть повній переробці та нейтралізації соціально-психологічної дезадаптації й усуненню віддалених наслідків стресогенних впливів.

Ключові слова: посттравматичний стресовий розлад, психологічна травма, соціальна адаптація, гіперактивація, гіперпильність.

Постановка проблеми. Суспільно-політична та соціальноекономічна ситуація в нашій країні істотно підвищує рівень ризику виникнення тих чи інших психологічних розладів, зокрема через розширення спектра стресових чинників, поглиблення рівня їх інтенсивності та поширеності серед певних категорій населення. Критичного значення стресові чинники набувають серед учасників АТО, адже участь у бойових діях суттєво впливає на психоемоційний стан усіх учасників і $€$ причиною виникнення у них різноманітних психологічних розладів. За офіційними даними, під час бойових дій гине менше військовослужбовців, ніж ветеранів війни після їі закінчення, внаслідок впливу на них психічних травм. Серед різновидів психічної патології в учасників бойових дій значне місце посідають посттравматичні стресові розлади - відстрочені затяжні реакції на екстремальні події, не пов'язані з органічними ушкодженнями головного мозку, що спостерігаються упродовж тривалого періоду і можуть викликати суттєві зміни особистості й поведінки.

У наш час наявність значної кількості людей із посттравматичним стресовим розладом у всьому світі загалом та в Україні зокрема спонукає до детальнішого дослідження критеріїв цього розладу, диференційної діагностики ПТСР. Така необхідність виникає і через наявність впливу цих розладів на соціальні процеси і працездатність.

Аналіз останніх досліджень і публікацій. Різні аспекти вивчення процесу перебігу і механізмів посттравматичного стресового розладу були висвітлені у працях таких дослідників, як: К. О. Абульханова-Славська, О. В. Брушлінський, Л. Ф. Бур- 
лачук, Є. І. Головаха, В. М. Доній, О. О. Кронік, В. О. Моляко, Г. М. Несен, С. Л. Рубінштейн, В. О. Татенко, А. В. Тимченко, Т. М. Титаренко, С. І. Яковенко. Дослідження воєнного стресу (В. Г. Василевський, А. Б. Довгополюк, Г. О. Растовцев, Т. Б. Дмитрієва, Е. М. Спачинцева, С. В. Литвинцев, С. В. Снєдков, Г. М. Тимченко, Г. А. Фастовцев, О. М. Харитонов та інші) засвідчили, що бойові посттравматичні стресові розлади різноманітніші й часто бувають тривалішими, ніж посттравматичні стресові розлади мирного часу через кумульовані (накопичені) в пам'яті, багаторазово пережиті жахи війни, фізичне і психічне перенапруження, горе втрат, співпереживання з пораненими. Проте велику кількість матеріалів і досліджень не систематизовано і не узгоджено між собою, деякі з них містять протиріччя у визначенні чинників розладів і алгоритму їх діагностики. Тому аналіз і систематизація даних про симптоми й критерії розладу дає змогу створити дієві засоби і методи профілактики.

Результати численних досліджень показали, що психологічний стан, який розвивається внаслідок впливу бойової обстановки та бойових дій, не належить до жодної з відомих у клінічній практиці класифікацій. Наслідки травми можуть проявитися раптово, через тривалий час, на тлі загального зовнішнього благополуччя військовослужбовців, і згодом це погіршення стану стає усе чіткіше вираженим. Низку різноманітних симптомів подібної зміни стану було описано раніше, проте довгий час не розроблялися чіткі критерії його діагностики. На тлі високої актуальності соціально-психологічного вивчення феномену психічної травми, стримуючий вплив на емпіричні дослідження чинить відсутність узгодженості теоретичної позиції, концептуальних моделей і методичних розробок, що дозволять достатньо повно і всебічно аналізувати цей феномен і порівнювати результати вивчення у соціальному контексті.

Мета статті - дослідити та систематизувати наукові й практичні знання про природу, механізми виникнення і типові прояви посттравматичного стресового розладу в соціальному просторі.

Виклад основного матеріалу. Посттравматичний стресовий розлад - це непсихотична відстрочена реакція на травматичний стрес, здатна викликати низку психічних і поведінкових порушень. Для виникнення ПТСР необхідно, щоб людина випробувала дію стресора, який виходить за межі звичайного людського досвіду і здатний викликати дистрес [4, с. 255]. До основних 

симптомів синдрому ПТСР належать: порушення сну; патологічні спогади (нав'язливі повернення); нездатність згадати - амнезія на деякі події (уникнення); надчутливість (підвищена пильність); надзбудження (неадекватна надмобілізація) [3, с. 95]. До вторинних симптомів ПТСР відносять: депресію, тривогу, імпульсивну поведінку, алкоголізм, соматичні розлади, порушення «Его»-функціонування тощо.

Розлади завжди виникають як прямий наслідок гострого важкого стресу або пролонгованої травми. Стресова подія або тривалі неприємні обставини є первинним і основним причинним фактором, і розлад би не виник без їхнього впливу. До цієї категорії віднесено реакцію на важкий стрес і розлади адаптації в усіх вікових групах, включаючи дітей і підлітків. Кожен з окремих симптомів, із яких складається гостра реакція на стрес і розлад адаптації, може зустрічатися і при інших розладах, але наявні деякі особливі ознаки того, як проявляються ці симптоми, що виправдовує поєднання цих станів у клінічну одиницю. ПТСР має відносно специфічні й характерні клінічні ознаки. Ці розлади можна розглядати як порушення адаптаційних реакцій на важкий пролонгований стрес, вони перешкоджають дії механізму адаптації, призводять до порушення соціального функціонування [5, с. 145-151]. ПТСР розвивається внаслідок отриманої важкої психічної травми. Психічна травма визначається як невідворотна подія, що руйнує існуючі копінг-механізми індивіда.

При посттравматичному стресовому розладі особистість може мати труднощі з прийняттям минулого досвіду, підтримуванням міжособистісних стосунків із родиною та друзями, довірою до інших людей, інтересом до видів активності, які раніше приносили задоволення, та в обговоренні своїх почуттів з оточуючими. Інші симптоми, такі як безсоння, відчуття провини, уникаюча поведінка, емоційна нечутливість, є дуже поширеними й призводять до значного дистресу й ускладнення повсякденного функціонування.

А. Кардинер, досліджуючи ПТСР, назвав це явище «хронічним військовим неврозом» і показав, що військовий невроз має як фізіологічну, так і психологічну природу. Він уперше дав комплексний опис симптоматики: збудливість і дратівливість; нестримний тип реагування на раптові подразники; фіксація на обставинах травматичної події; відхід від реальності; схильність до некерованих агресивних реакцій [9, с. 12]. 
На думку А. І. Красило, психологічна травма - це катастрофічне руйнування особистісної самооцінки внаслідок втрати або загрози недосяжності сенсоутворюючих соціальних цінностей. Умовою зростання цих цінностей є особистісний розвиток у масштабі конкретної травматичної зони постраждалого. Нерівномірність розвитку психіки закріплюється у внутрішніх установках і стає бар'єром набуття єдності та цілісності особистості. I навпаки, позитивним чинником, що сприяє попередженню психологічного травматизму, є рання гармонічна соціалізація індивіда. Важливо визначити і закріпити ті потенційні можливості індивіда, що надають особистості змогу протистояти чинникам, які сприяють її розпаду і сповзанню на шлях соціальної невротизації.

Англійський учений С. Касл виокремив два основні трактування поняття стресу в зв'язку з трудовою діяльністю - звужене та розширене. У першому трактуванні стрес розглядається як переважання вимог середовища над тими наявними можливостями суб'єкта, що необхідні для їх задоволення (наявність перевантаження, надстимуляціі). У другому - як неадекватність у цілісній системі «людина - середовище», що включає не тільки звужене тлумачення, але й зв'язок між потребами людини і можливостями їх задоволення в трудовому середовищі (недовикористання людських можливостей, знижене навантаження, низька стимуляція) [11, с. 3].

Єдиної теорії патогенезу посттравматичних стресових розладів немає. Причина полягає не тільки у складності посттравматичного стресу, але і в тому, що під його багатогранністю відбуваються різні адаптивні й дезадаптивні процеси. Тому багато дослідників і клініцистів, грунтуючись на різних гіпотезах, запропонували різні психологічні й інші моделі: психодинамічну, когнітивну, психосоціальну, психобіологічну, умовно-рефлекторну i, розроблену в останні роки, мультифакторну модель посттравматичного стресового розладу.

Аналізуючи ПТСР, Є. О. Александров спирається на диференціацію розгорнутої картини стресу на субсиндроми: емоційно-психологічний, вегетативний, когнітивний та соціально-психологічний. Так, об'єднуючи в собі основні підходи, був розроблений психосоціальний підхід, де вводиться вплив зовнішнього середовища на виникнення посттравматичного стресового розладу. Ця модель реагування на травму також є багатофакторною $\mathrm{i}$ враховує вагу кожного чинника у розвитку реакції на стрес. У 
ній виокремлено соціальні чинники, що впливають на успішність адаптації постраждалих від психічної травми, такі як: відсутність фізичних наслідків травми, міцне фінансове становище, збереження колишнього соціального статусу, чинник соціальної підтримки з боку суспільства й значущий чинник впливу близьких людей [4, с. 117].

Відповідно до DSM-5, депресивні розлади характеризуються сумним, спустошеним чи дратівливим настроєм і супроводжуються соматичними та когнітивними змінами, які суттєво впливають на якість життя людини [10, с. 155]. Найвідомішим із них є «великий депресивний розлад», який діагностують у випадку наявності мінімум п’яти з перелічених симптомів, присутніх упродовж останніх двох тижнів: пригнічений настрій упродовж більшої частини дня, значне зниження інтересу чи задоволення від більшості активностей, значна зміна ваги тіла чи апетиту, надмірна сонливість або безсоння, психомоторне збудження або загальмованість, відчуття нестачі енергії, почуття меншовартості або провини, знижена здатність до концентрації уваги та повторювані думки про власну смерть, суїцидальні наміри чи спроби.

На сьогоднішній день у західний психології існує стандартна практика використання структурованого діагностичного інтерв’ю для того, щоб переконатися у детальному врахуванні усіх симптомів ПТСР. Діагностичне інтерв'ю поєднує переваги точних рекомендацій із виявлення того чи іншого діагнозу й методу інтерв'ю, що відповідає конкретним психометричним параметрам (надійність і валідність). Використання структурованого діагностичного інтерв'ю в клінічній практиці може суттєво підвищити точність діагнозу і покращити планування лікування.

Важливу роль у когнітивному посттравматичному процесі відіграють дисоціативні стани, пов'язані з особливостями реакції процесів пам'яті на травмуючу інформацію, що супроводжуються різноманітними відчуттями втрати зв'язку з реальністю. Часто можуть проявлятися мимовільні перенесення людини в травматичне минуле та здійснення нею дій, адекватних не теперішній ситуації, а ситуації в минулому. Відмова від прийняття життєвого досвіду і породжує основну причину посттравматичної дезадаптації - когнітивний конфлікт, суть якого в тому, що травматичні спогади проривають бар’єр заборон. Інтенсивність емоцій при проривах спогадів постійно збільшується. Із часом важкість емоційного стану, що супроводжує травматичні спогади, робить неможливим нормальне функціонування людини [7; 8]. 
Соціальний стресовий розлад виявляється доклінічними (психологічні реакції) і клінічними (невроз, патохарактерологічний розвиток особистості, алкоголізм) розладами. Основні клінічні прояви соціального стресового розладу: вегетативні дисфункції; порушення сну; астенічні розлади; істеричні розлади; панічні розлади; інші невротичні та психопатичні порушення. Особливо показовими є прояви соціального стресового розладу в осіб із вимушеною міграцією. Автори під час обстеження мігрантів звертають увагу на високий ступінь ризику психогенних розладів (Н. Г. Незнанов, К. К. Телія).

Поняття «соціально-психологічна дезадаптація» охоплює широке коло порушень, що можуть виникнути у молоді під дією різноманітних складних соціальних умов, обставин їі життя (фактичне або соціальне сирітство, розлучення чи конфлікти в сім’̈̈, зміна місця проживання або звичної обстановки, тривала хвороба, фізичний недолік тощо).

Соціальна адаптація - це діяльність, спрямована на оптимізацію взаємовідносин людини з оточуючим середовищем, що полягає в оцінці ситуації та корекції на цій основі як поведінки людини, так і стану оточуючого її соціального середовища [1, с. 84]. Соціальна адаптація особистості спрямована на відновлення норм, соціально-корисних відносин із соціальними суб'єктами (групами й окремими їх членами), зміну в позитивному плані спілкування, поведінки, діяльності.

Психологічна адаптація - це засвоєння соціально корисних стандартів поведінки та ціннісних орієнтацій, зближення установок і направленості особистості з очікуваннями соціального середовища. Соціальна і психологічна сторони адаптації перебувають у нерозривній єдності, хоча іноді можуть не збігатися.

Потенціал подолання стресогенних подій полягає у виборі успішних пристосувальних стратегій поведінки, а рівень розвитку і репертуар механізмів мають величезне значення як для соціально-психологічного функціонування особистості, так і для збереження психічного благополуччя. Ефективність соціальнопсихологічної адаптації визначається як за об’єктивними показниками досягнень, так і за суб'єктивною задоволеністю людини своїми досягненнями у тій професійній та соціально-економічній позиції, яку вона займає.

О. Ісаєва встановила, що поведінка, яка дозволяє впоратися зі стресом, має вікові та гендерні відмінності, може змінюватися упродовж життя залежно від завдань і вимог, що висуваються до 
людини середовищем на різних етапах онтогенезу і соціогенезу. Автор стверджує, що репертуар поведінки для подолання стресу в поєднанні з механізмами психологічного захисту являє собою широкий спектр різноманітних варіантів: від гнучких, ситуаційно обумовлених стратегій подолання труднощів до стійких особистісних паттернів (стилів) реагування. Його потенційна адаптивність залежить від співвідношення ступеня вираженості свідомих і несвідомих форм адаптаційних механізмів особистісного функціонування. Стійкі сполучення стилів поведінки подолання стресу визначають характер (специфіку) психічної адаптації і рівень пристосувальних можливостей особистості; вони є одними з параметрів, складових поняття «психологічної вразливості» особистості, розгляд якої необхідно проводити тільки у разі обліку особистісних ресурсів [2, с. 6].

Копінг-стратегії - це стратегї̈ врегулювання взаємовідносин із навколишнім середовищем. Ці стратегії пов' язані з такими поняттями, як життєстійкість і стресостійкість. Копінг-поведінка виникає тоді, коли людина потрапляє в кризову ситуацію. Провідними характеристиками кризової ситуації є психічна напруженість, значущі переживання як особлива внутрішня робота з подолання життєвих подій або травм, зміна самооцінки і мотивації, а також виражена потреба в їх корекції ззовні. У деяких теоріях копінг-поведінки виділяють такі базисні стратегії: вирішення проблем; пошук соціальної підтримки; уникнення $[6$, с. 22].

Велике значення для забезпечення підтримуючих соціально-психологічних умов хворих має адекватне сприйняття захворювання, його причин та наслідків у суспільстві, нормальне ставлення громадян до таких хворих у побутових і професійних ситуаціях. Досягти цього можна шляхом проведення державою відповідних роз'яснювальних, інформативних заходів, зокрема з використанням соціальної реклами, соціальних мереж тощо.

Стосовно сучасних методів психологічної коригуючої терапії, слід виділити арт-терапію й анімалотерапію. Цікавим є досвід обласного шпиталю ветеранів війни, де активно проводять роботу з учасниками АТО досвідчені психологи, психотерапевти. Психокорекційні заняття, побудовані з використанням методів арт-терапії, дають змогу учасникам АТО дистанціюватися від травматичних переживань, зафіксованих переважно у невербальних образах, шляхом їх об'єктивізації та зображення у візуальних образах, дати вихід внутрішнім конфліктам і сильним 
емоціям, інтерпретувати витіснені переживання, сприяють усвідомленню власних відчуттів і почуттів. Арт-терапія надає змогу не лише творчо самовиразитися, але й більше пізнати себе, виразити свій внутрішній світ через творчість. Поєднання вербальної та невербальної експресії сприяє переробці й переосмисленню травматичного досвіду. Арт-терапія не вимагає особливих здібностей або художніх навичок, а тому не має обмежень у використанні. Потрібно зазначити, що у процесі творчого самовираження можливий вибуховий вихід сильних емоцій, що вимагає від психолога особливої підготовки. Завдяки використанню методу арт-терапії задіюються два механізми психокорекційного впливу: реконструювання травмуючої ситуації в особливій символічній формі та її вирішення шляхом переструктурування на основі креативних здібностей.

Використання анімалотерапії сприяє зняттю стресу, нормалізації роботи нервової системи та психіки, самореалізації, спілкуванню. Для хворих із ПТСР особливо важливими результатами використання анімалотерапії є отримання навичок, що сприяють гармонізації міжособистісних відносин із людьми, психічній і соціальній реабілітації.

Висновки. Посттравматичний стресовий розлад виникає після дії травматичних ситуацій, що характеризуються екстремальними критичними подіями, які несуть у собі надзвичайно негативний вплив, ситуацію загрози життю чи здоров'ю людини, потребуючи від неї екстраординарних зусиль з оволодіння наслідками цього впливу. ПТСР характеризується такими симптомами: причепливого, постійно повторюваного переживання травматичної події; симптомами уникнення, де травматичний досвід постійно витісняється зі свідомості (людина прагне позбутись думок і спогадів про пережите), що супроводжується високою емоційною напругою й енергетичним виснаженням; симптомами фізіологічної гіперактивації, що проявляються утрудненням засинання, підвищеною роздратованістю, спалахами гніву, невмотивованою гіперпильністю та постійною готовністю до загрози (небезпеки). Розвиток посттравматичного стресового розладу залежить від багатьох умов, а саме: наскільки ситуація суб'єктивно сприймається як загрозлива, наскільки об'єктивно реальною була загроза життю, наскільки близько від трагічних подій перебував індивід, чи були задіяні в цій події його близькі, чи вони постраждали. 
Соціальні наслідки цього розладу охоплюють значно ширші категорії населення, що вимагає активної та виваженої роботи закладів сфери охорони здоров'я щодо раннього виявлення та лікування ПТСР. Основними і найбільш значущими методами, що мають використовуватись додатково до традиційної психологічної терапії, є створення сприятливих соціально-психологічних умов життя хворих і застосування сучасних методів психологічної корекції, зокрема арт-терапії й анімалотерапії.

Подальші напрямки досліджень: психодіагностика вікових, гендерних особливостей проявів посттравматичного стресового розладу; методологічне забезпечення процесу реадаптації та реабілітації учасників бойових дій.

\section{Список використаних джерел}

1. Безпалько О. Соціальна педагогіка в схемах і таблицях : навч. посіб. / О. Безпалько. - К. : Центр навчальної літератури, 2003. - 134 с.

2. Исаева Е. Совладающее со стрессом и защитное поведение личности при расстройствах психической адаптации различного генеза : автореф. дис. ... докт. псих. наук : спец. 19.00.04 / Елена Исаева. - СПб., 2010. - С. 4-15.

3. Ломакін Г. І. Прояви порушень реадаптації учасників бойових дій у системі суспільних відносин / Геннадій Іванович Ломакін // Проблеми емпіричних досліджень у психології : Матеріали VI Міжнародної науково-практичної конференції (6-7 грудня 2012 р., м. Київ) / за ред. І. В. Данилюка, I. В. Ващенко. - К. : ОВС, 2012. - С. 94-100.

4. Малкина-Пых И. Г. Психологическая помощь в кризисных ситуациях / Ирина Германовна Малкина-Пых. - М. : Изд-во «Эксмо», 2005. - 960 с.

5. Международная классификация болезней (10-й пересмотр). Клинические описания и указания по диагностике. - Киев : Cфpepa, 2005. - С. 145-151.

6. Нартова-Бочавер С. «Coping Behavior» в системе понятий психологии личности / С. Нартова-Бочавер // Психологический журнал. - 1997. - Т. 18. - № 5. - С. 20-30.

7. Писаренко В. М. Устойчивость эмоционального состояния спортсмена в условиях соревнований / В. М. Писаренко // Пути достижения трудной цели в спорте. - M., 1964. - С. 5168. 
8. Пірен М. І. Конфлікт і управлінські ролі. Соціо-психологічний аналіз / М. І. Пірен. - К. : МАУП, 2000. - 284 с.

9. Пограничные нервно-психические нарушения у ветеранов войны в Афганистане : методические рекомендации / Б. Д. Цыганков, А. И. Белкин, В. А. Веткина и др. - М., 1992. $-16 \mathrm{c}$.

10. American Psychiatric Association. Diagnostic and statistical manual of mental disorders: DSM-5. - Washington, D. C. : American Psychiatric Association, 2013. - 947 p.

11. Kasl S. Epidemiological contributions to the study of work stresses / S. Kasl / / Stress at work / C. Cooper, R. Payne (ed). Chichester : Wiley, 1978. - P. 3-48.

\section{Spysok vykorystanyh dzherel}

1. Bezpal'ko O. Social'na pedagogika v shemah i tablycjah : navch. posib. / O. Bezpal'ko. - K. : Centr navchal'noi' literatury, 2003. $-134 \mathrm{~s}$.

2. Isaeva E. Sovladajushhee so stressom i zashhitnoe povedenie lichnosti pri rasstrojstvah psihicheskoj adaptacii razlichnogo geneza : avtoref. dis.... dokt. psih. nauk : spec. 19.00.04 / Elena Isaeva. - SPb., 2010. - S. 4-15.

3. Lomakin G. I. Projavy porushen' readaptacii' uchasnykiv bojovyh dij u systemi suspil'nyh vidnosyn / Gennadij Ivanovych Lomakin // Problemy empirychnyh doslidzhen' u psyhologii' : Materialy VI Mizhnarodnoi' naukovo-praktychnoi' konferencii' (6-7 grudnja 2012 r., m. Kyi’v) / za red. I. V. Danyljuka, I. V. Vashhenko. - K. : OVS, 2012. - S. 94-100.

4. Malkina-Pyh I. G. Psihologicheskaja pomoshh' v krizisnyh situacijah / Irina Germanovna Malkina-Pyh. - M. : Izd-vo «Jeksmo», 2005. - 960 s.

5. Mezhdunarodnaja klassifikacija boleznej (10-j peresmotr). Klinicheskie opisanija i ukazanija po diagnostike. - Kiev : Sfera, 2005. - S. 145-151.

6. Nartova-Bochaver S. "Coping Behavior» v sisteme ponjatij psihologii lichnosti / S. Nartova-Bochaver // Psihologicheskij zhurnal. - 1997. - T. 18. - № 5. - S. 20-30.

7. Pisarenko V. M. Ustojchivost' jemocional'nogo sostojanija sportsmena v uslovijah sorevnovanij / V. M. Pisarenko // Puti dostizhenija trudnoj celi v sporte. - M., 1964. - S. 51-68.

8. Piren M. I. Konflikt i upravlins'ki roli. Socio-psyhologichnyj analiz / M. I. Piren. - K. : MAUP, 2000. - 284 s. 
9. Pogranichnye nervno-psihicheskie narushenija $u$ veteranov vojny v Afganistane : metodicheskie rekomendacii // B. D. Cygankov, A. I. Belkin, V. A. Vetkina i dr. - M., 1992. - $16 \mathrm{~s}$.

10. American Psychiatric Association. Diagnostic and statistical manual of mental disorders: DSM-5. - Washington, D. C. : American Psychiatric Association, 2013. - 947 p.

11. Kasl S. Epidemiological contributions to the study of work stresses / S. Kasl / / Stress at work / C. Cooper, R. Payne (ed). Chichester : Wiley, 1978. - P. 3-48.

Received January 25, 2018

Revised February 13, 2018

Accepted March 2, 2018

\section{УПрАвлінНЯ МОТИВАЦією ПрОфЕСійНОї} АіЯАЬНОСТі ПЕААГОГічНИХ ПРАЦіВНИКіВ ЗАГААЬНООСВіТНіХ НАВЧАЛЬНИХ ЗАКАААІВ

Pastukh L. V. Managing the motivation of teachers' professional activities at comprehensive schools / L. V. Pastukh // Problems of Modern Psychology : Collection of research papers of Kamianets-Podilskyi National Ivan Ohiienko University, G. S. Kostiuk Institute of Psychology of the National Academy of Educational Sciences of Ukraine / scientific editing by S. D. Maksymenko, L. A. Onufriieva. - Issue 40. Kamianets-Podilskyi : Aksioma, 2018. - P. 306-320.

L. V. Pastukh. Managing the motivation of teachers' professional activities at comprehensive schools. The urgency of studying the problems on managing the motivation of teachers' professional activities at comprehensive schools, defined by strategic state educational documents, is actualized in the article. The foreign theories of motivation of professional activities are generalized. It is stated that although they are developed on the basis of western experience, it is important to use their ideas practically in the motivational management of the heads of educational institutions of modern Ukraine. This is illustrated by examples of specific recommendations for managers.

The problems and disadvantages of management of the motivation of teachers' professional activities are distinguished. 